\title{
A Constructivist Institutionalism Perspective of Disaster and Crisis Countermeasure in Indonesia
}

\author{
Ari Darmastuti ${ }^{1,2, *}$ \\ ${ }^{1}$ Department of International Relations, University of Lampung, 35145 Bandar Lampung City, \\ Indonesia \\ ${ }^{2}$ Department of Government Studies, University of Lampung, 35145 Bandar Lampung City, \\ Indonesia \\ *) Corresponding Author (e-mail: ari.darmastuti@fisip.unila.ac.id)
}

Received: 16 August 2020 / Accepted: 25 November 2020 / Published: 10 December 2020

\begin{abstract}
As a country that lies in the area known as the Ring of Fire, Indonesia is prone to many disasters and the aftermaths of such crises, from low-scale earthquake events up to mega-magnitude tsunami, earthquakes and volcanoes. The current Covid-19 pandemic is another disaster in mega magnitude scale that the country must deal with. Research on disaster risk reduction and management has been conducted, yet little is known about how governments, as the most important actor in disaster countermeasures, develop their institutions based on unpredictable exogenous factors. This study aims to critically analyse disaster and crisis countermeasures in Indonesia based on a constructivist perspective. The data for this qualitative study were mainly collected through document studies, together with some interviews. The mega-crisis due to the Covid-19 pandemic has resulted in the establishment of long-term national, provincial, local, and lower-level task forces all over Indonesia. This kind of institutional arrangement has never previously been developed in the country, not even after the 2006 mega-tsunami which hit various provinces and led to a huge death toll of over 100,000. The study shows that although the institutional arrangements for disaster countermeasures in Indonesia are based on the same law, the implementation of institutional structures and practices as disaster countermeasures vary greatly.
\end{abstract}

Keywords: disaster management, crisis countermeasures, constructivist institutionalism perspective, Indonesia.

\section{Introduction}

As a nation that sits on the Ring of Fire, Indonesia faces many crisis and disasters all over the country of varying magnitudes, from small-scale ones such as local floods, up to the mega- magnitude tsunami which killed more than 100,000 Acehnese and North Sumatrans at the end of 2004. According to a report in a prominent national newspaper, Kompas, from January to April 2019 Indonesia suffered from 1538 disasters, resulting in 325 deaths, 113 missing, 1439 injured, and 996,143 temporary refugees (Kompas, 2019). According to the news, 3588 houses were seriously damaged, 3289 moderately damaged, and 15,376 slightly damaged.
Up to December 2019, the total number of disasters was 3768, with 478 deaths, 109 missing, 3419 injured, 6.1 million temporary refugees, and 73,427 damaged houses (Voice of Indonesia, 2019). Most of the disasters (3,731, or 99\%) were hydrometeorologic ones and $1 \%$ geological. In addition, based on an official report by BNPB (National Boards for Disaster Countermeasures) (BNPB, 2020), from early 2020 up to 18 May 2020 there had been 1296 disasters in Indonesia, which were dominated by flash floods, thunderstorms, volcano eruptions, and landslides (See Figure 1). These consisted of five earthquakes, three mountain eruptions, 120 forest fires, one fire, 495 floods, 291 landslides, 375 thunderstorms, five tidal 
waves, and one pandemic. As the result of the disasters (excluding Covid victims), there were 178 deaths, eight people missing, 249 injured, and 2,015,363 considered as temporary domestic refugees. In terms of property damage, 17,563 houses were damaged (3891 severely, 2551 moderately, and 11,121 slightly); and 759 public facilities were damaged (331 education facilities, 369 commercial facilities, and 32 health facilities). In the same period, Covid-19 led to 17,514 positive cases and 1148 deaths, while based on the latest $\mathrm{BNPB}$ report (BNPB, 2020), there were 123,503 positive Covid cases and 5658 deaths.

As a country highly prone to disasters, Indonesia needs strong institutional arrangements to deal with them. The most important actor in conducting disaster countermeasures is the government, in this case the Government of Indonesia (GoI).
Although government always works with other stakeholders (domestically and internationally) to counter disasters, success or failure will greatly depend on government policies both in its anticipation and response. In a previous paper (Darmastuti and Rosalia, 2019), we presented the argument that although the government has developed a multi stakeholder partnership (MSP) with local communitybased organizations (CBO), non-government organizations (NGO), professional groups and other groups, its failure to develop a network partnership (a strong institutional partnership between government institutions and other disaster stakeholders) has created a critical situation in countering tsunami. Therefore, it is important to study in more detail how the government could develop institutional arrangements to counter disasters in a better fashion.

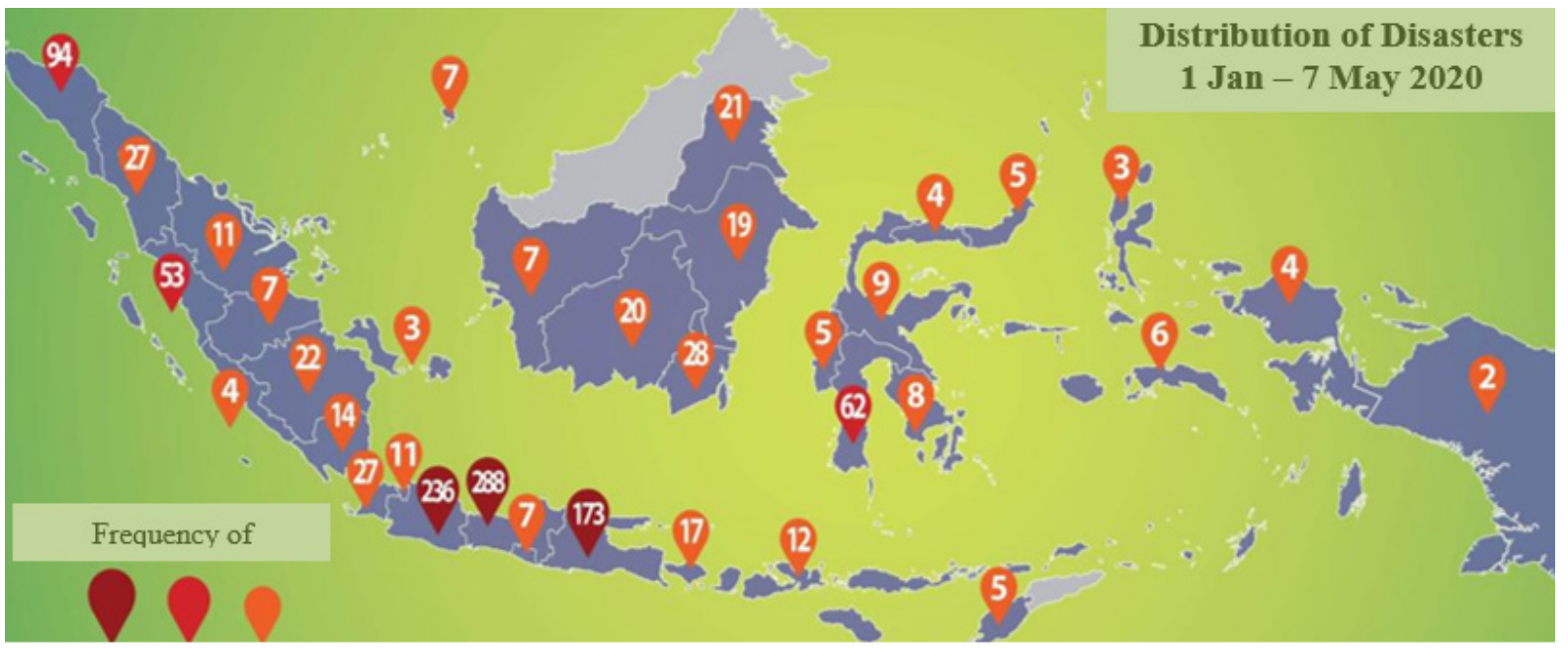

Figure 1. Distribution of disasters in Indonesia (BNPB, 2020)

2. Crisis and disaster institutional arrangements: literature and theoretical perspectives

A review of previous research on institutional arrangements for disaster countermeasures showed that governments, including local ones, are important actors in disasterriskreduction(Malalgoda, Amaratunga and Pathirage, 2010). It was claimed that local governments, being the first responder and responsible for community development, plays a significant role in conducting disaster risk reduction (DRR) initiatives. However, shortages in financial, manpower and resource availability may prevent them from making timely decisions and responses to disasters. Therefore, local governments need to improve their institutional structures and performance. Jones et al., (2014) present similar point of view in relation to the importance of the government role in DRR in Nepal, stating that although national government may not be genuinely 
working in taking DRR initiatives due selfinterest, genuine DRR from national and international non-government organizations (NGOs), multilateral agencies and donors can lead to considerable progress in such initiatives. They claim that in post-conflict and weak states, support from NGOs and international agencies and donors are key elements in ensuring that DRR initiatives work efficiently.

In time-series cross-sectional data research, Persson and Povitkina (2017) linked disaster countermeasures with the performance of democracy. They argue that democracy may lead to fewer disaster-affected people only when there is good institutional quality. Otherwise, people may suffer more in democracies than in authoritarian states. Goyal (2019) analyzed disasters in India and showed that inadequate preparedness and disaster mitigation may push back development by decades. The inability of states to translate scientific warnings of disasters into first line responders and to the community leads to greater risks in affected communities. The study highlighted the importance of intitutional decentralization, as well as more active community participation, in order to create a better and anticipative framework for DRR in order to change the previous post-disaster releief and rehabilitation approach.

However, Walch (2017) highlighted adaptive governance as the most crucial arrangement, since it enables governments to embrace disaster uncertainty by enlarging the potential for collaboration, flexibility, and learning. The study shows that adaptive governance in DRR remains underdeveloped and understudied. In addition, it will only succeed under two conditions: government's ability to turn the aftermath of the shock of disasters into serious rethinking, and its ability to reform previous governance practices into a more resilient system.

Indonesia is an archipelago which experiences disasters on all scales, from small insignificant ones, up to highly disastrous ones. Many studies have been conducted related to DRR management. However, serious research with critical analysis based on the constructivist intitutional perspective which seeks a clear picture of how govenment institutions reform previous governance practices into a more resilient system to countermeasure disasters and crisis has yet to be conducted, especially in the Indonesian context. This study therefore aims to fill this knowledge gap.

Furthermore, in the context of theoretical discussion of the subject of institutional arrangements for crisis and disasters, it is necessary to take into account the critical point of view as to how problems related to state and state capacity may influence the capability of governments to overcome crisis and disasters (Glassbergen, 2009). This includes (1) the erosion of state capacity; (2) democratic shortcomings (problems with representation and accountability); and (3) arguments related to fragmentation (of ideas, interests, priorities, etc). Glassbergen states further that the problem of erosion of state capacity is compensated by the financial capacity of business sectors and other motives they may have, such as gaining social recognition through corporate social responsibility (CSR). Glassbergen states further that problems with representation and accountability make the roles of the private sector and civil society in global politics and policy more salient; policies developed outside formal state channels are no less important than formal state-driven ones. Meanwhile he says problem of fragmentation (of formal norms and regulations) may stimulate innovation based the norms, regulations, theories, and stories from business and civil society. Further, Glassbergen argues that these three problems of state capability may be compensated for by working together with other disaster stakeholders through an institutional arrangement called meta-governance or governance of governances.

It is important to note that although government institutions are the most important actors in the counter-measuring of disasters, government may have shortcomings due to the complexity of crisis and disaster management; may face financial difficulties or even financial 
crisis; have limited human resources; and suffer from inflexibility in the hierarchical authorities linking the state with local-level micro-practices of social innovation and self-government (Amore and Hall, 2015; Boin, Ekengren, and Rhinard, 2006). In addition, it may be incapable of linking private and local governance (Beisheim et al., 2017; Bell and Park, 2006). In a previous study, Darmastuti and Rosalia (2019) argued that government may choose one type of institutional arrangement to link it with other disaster and crisis stakeholders, namely a multi-stakeholder or network partnership. The study revealed that the aftermath of the tsunami in Lampung Province in Indonesia at the end of 2018 was managed through multi-stakeholder partnership (MSP) meta-governance, in which many institutions worked together by using their own respective rules, resources, and capabilities to join other stakeholders in countering the effects of the tsunami disaster.

It should be taken into consideration that this research primarily focuses on how stateconstructed rules, institutions and practices (at the national, regional and local levels) can be used as countermeasures for disasters and crises, including the latest mega disaster and the crisis of the Covid-19 pandemic. It focuses on more detailed questions such as how rights and responsibilities are shared and put into action in the wake of disasters and crises. The following section will describe the theoretical perspective on institutional arrangements based on new institutional approach, namely constructivist institutionalism. According to March and Olsen (2006: 4) the term 'institution' means:

"A relatively enduring collection of rules and organized practices, embedded in structures of meaning and resources that are relatively invariant in the face of turnover of individuals and relatively resilient to the idiosyncratic preferences and expectations of individuals and changing external circumstances (March and Olsen 1989, 1995). There are constitutive rules and practices prescribing appropriate behaviour for specific actors in specific situations. There are structures of meaning, embedded in identities and belongings: common purposes and accounts that give direction and meaning to behaviour, and explain, justify, and legitimate behavioural codes. There are structures of resources that create capabilities for acting. Institutions empower and constrain actors differently and make them more or less capable of acting according to prescriptive rules of appropriateness. Institutions are also reinforced by third parties in enforcing rules and sanctioning non-compliance".

Some key features of the concept of institutions are rules, organized practices, structures, preferences, expectations, individuals and external circumstances. The concept also conveys other aspects such as structured meanings, identities, common purposes and accounts that justify and legitimate behavioral codes. It also covers prescriptive rules of appropriateness which are always reinforced by third party rules and used as a tool for sanctioning non-compliance.

Institutions can also be studied based on several theories; for example, "old/normative, historical, rational choice, constructivist, and network institutionalism" (Rhodes et al., 2006: 23-111). In short, old/normative institutionalism studies institutions through an analysis of how values are manifested in its rules and respective structures. On the other hand, historical institutionalism considers institutions through their changes over time in adjusting to changes in the environment, while rational choice institutionalism examines the "best means to achieve the best results" by taking into account the potential of others' responses. Constructivist institutionalism cited in Rhodes et al. (2006: 56-57), intends to capture, describe, and interrogate complex changes and disequilibrium. It focuses on post-formative changes, while historical institutionalism tends to analyze past changes. It is stated further that constructivist institutionalism has the potential to overcome the weakness of rational choice institutionalism, since in the logic of rational choice, changes are always predictable, while constructivist argues that structural changes are mostly unpredictable, in the same way that coral reefs always grow differently due 
to unpredictable environmental changes. This argument makes constructivist institutionalism the best theoretical perspective to study disasters and institutional crisis arrangements, since the nature of disasters is almost always unpredictable. As such, structural changes (rules, institutions, and practices) will be the focus of the analysis of disasters and institutional crisis arrangements with regard to cases of recent disasters and crises in Indonesia.

\section{Research Method}

A qualitative method was applied in this study, Jackson et al., (2007: 21) explain that "qualitative research is primarily concerned understanding human beings' experiences in a humanistic, interpretive approach. Two techniques were used to gather the data in this research. The first was by making a qualitative assessment and analysis of certain official documents, such as presidential decrees, laws and institutional reports (especially taken from $\mathrm{BNPB}$, the Indonesian Red Cross, Ministry of Social Affairs, Ministry of Health, Gugus Tugas Percepatan Penanganan COVID-19 or Task Force for Acceleration of Covid-19 Countermeasures/TFAC, etc). Information was also used taken from news and other documents such as government reports collected during the course of study. Second, in order to strengthen the document analysis, interviews were also applied to collect supporting data, especially with regards to the practice of disaster countermeasures by BNPB, the main government institution responsible for these. Discussion with experts and practitioners is also important, especially when analyzing data gathered from the field. The data analysis was conducted using content analysis. Jackson et al., (2007: 24) note that this is "a generic name for a variety of ways for conducting systematic, objective, quantitative, and/or qualitative textual analysis that involves comparing, contrasting, and categorizing a set of data primarily to test hypotheses".

\section{Results and Discussion}

\subsection{Institutional arrangements in the field of crisis and disaster in Indonesia}

In the wake of the Covid-19 pandemic in Indonesia, which was declared a national disaster by the Government of Indonesia (GoI) in early March 2020, the President of the Republic of Indonesia signed Decree number $7 / 2020$ on the establishment of TFAC at the national level. This aimed to (1) improve the national health system and its performance; (2) accelerate Covid-19 countermeasures through inter-ministerial synergy, as well as synergy with provincial and local governments; (3) improve anticipation capacity to contain the spread of the pandemic; (4) improve operational decision-making synergy; and (5) improve preparedness and responses to Covid-19.

According to the decree, TFAC consists of two main sub-structures, the steering committee and the operational/managerial committee. The operational/managerial committee has the duties to: (1) conduct daily operation of the Covid-19 operational plan; (2) coordinate and control Covid-19 countermeasure activities; (3) supervise Covid-19 countermeasure activities; (4) deploy all resources to counter the pandemic outbreak; (5) and report to the president on all assigned duties. The operational/managerial structure consists of a chair (the Chair of the National Board for Disaster Countermeasures); vice chairs (Operational Assistant to the Indonesian Army Commander and Operational Assistant to the Indonesian Police Commander); and members (representatives of the Coordinator Ministry of Human Development and Culture, Health Ministry, Internal Affairs Ministry, Foreign Affairs Ministry, Transportation Ministry, Communication and Information Ministry, Education and Culture Ministry, Religious Affairs Ministry, National Board for Disaster Countermeasures, Indonesian Army, Indonesian Police, and Presidential Office Staff). Article 11 of the Decree stipulates that 
a similar task force is established in provincial and local levels.

Regarding operation, the decree states that the TFAC may develop partnerships or involve other ministries and offices, as well as the private sector and other stakeholders, when necessary. The TFAC is fully funded by the state budget. At provincial and local levels, the respective TFACs are fully funded by provincial or local budgets. The decree has also been used as the basis for diverting budget plans (at national, provincial, and local levels) from previous routine and development plans into a Covid-19 countermeasure budget without the common budget approval procedure through a long process of budget proposal submissions, discussions between executive and legislative bodies, and final acceptance or rejection of the budget. The decree states that the president, governors, and regents/city mayors need to notify the legislative bodies at their respective levels about budget changes. These bodies are not in a position to reject, or even to debate, the proposal, but are merely tasked to accept it unless there are serious suspicions of potential fraud. Budget diversion comes mostly from routine expenses such as staff travel, meetings and training, which have mostly been cancelled or postponed.

Considering the magnitude of the Covid-19 outbreak threat, similar task forces were established at provincial and local levels that resemble the national structure, meaning they consist of related government offices, the military, the police and other provincial and local stakeholders. Fast-track budget diversions have also been set up at provincial and local levels. Areas with extensive Covid-19 outbreaks, such as Greater Specific Region Jakarta, West Java, East Java, Central Java, South Sulawesi and South Kalimantan, may have larger budget diversions than other provinces with lower levels of cases.

Lower level task forces at sub-district and village levels have been established in most of Indonesia since the Covid-19 outbreak, which was formally acknowledged by the GoI in early March as having infected 130,718 people, with a death toll of 5,903 as of 11 August 2020 (BNPB, 2020). Adaptations were made based on the varying conditions, which may not be the same in all places. Areas with low or no Covid-19 cases may need only minor structures and small budgets, but areas with a high number of cases would need extensive structures and budgets.

The Covid-19 pandemic disaster in Indonesia has been the only disaster which has needed the establishment of task forces all over Indonesia and at all levels of government structure. There are some similarities in the institutional arrangements to guarantee working institutional procedures and operations. However, there are also differences in the adaptation to various conditions and situations. The institutional arrangements with regards to Covid-19 in Indonesia is a good example of how the proponents of constructivist institutionalism would argue. The following paragraphs will explain the different institutional arrangements for different types of disaster in Indonesia.

Following the tragedy of the tsunami in Aceh in 2004, which caused 165,708 deaths in Indonesia alone, with total deaths in the 12 affected countries of more than 225,000, the House of Representatives and GoI initiated the establishment of a Law number 24/2007 regarding Disaster Countermeasures, as the institutional foundation of such measures for all stakeholders (national to local). The law stipulates that the Government of Indonesia develop comprehensive Disaster Countermeasure Management in an effort to dynamically implement management functions at all stages of disaster countermeasures, from prevention to mitigation, emergency, rehabilitation and reconstruction. As mandated in the law, in 2008 the government established a new institution, currently known as BNPB, through Government Regulation number 8/2008 (BNPB, 2015a: 5-6), with main responsibilities regarding all stages of disaster countermeasures: (a) to develop guidelines and instructions for all stakeholders; (b) to decide standards and needs; (c) to inform and 
educate the public; (d) to report monthly to the president during normal periods and at any time during disaster periods; (e) to use and report on funds from national and international donors; (f) to report the use of the state budget; ( $\mathrm{g}$ ) to perform duties based on other regulations; and $(\mathrm{h})$ to develop guidelines for the establishment of the Provincial Board for Disaster Countermeasures (Badan Penanggulangan Bencana Daerah/ BPBD Provinsi). Based on these stipulations, the BNPB has established 34 BPBDs and 428 BPBDs at regency/city levels.

Policies in the field of crisis and disaster management are integral parts of the National Development Plan System (Law number 25/2004 regarding National Development
Plant System). Therefore, crisis and disaster management must be included in national, provincial, and regency/city long-term, midterm and annual planning. An interview with an informant from the National Board on 11 January 2019 revealed that there were some important points from the arrangement of disaster countermeasures in Indonesia: (1) disaster on a mass scale will be managed nationally by the BNPB, with the remainder depending on the scale and type of disaster; (2) crisis and disaster have become important issues in development planning in Indonesia; and (3) coordination between the many stakeholders remains difficult to implement, since disaster funds run through many tiers and branches of government agencies.

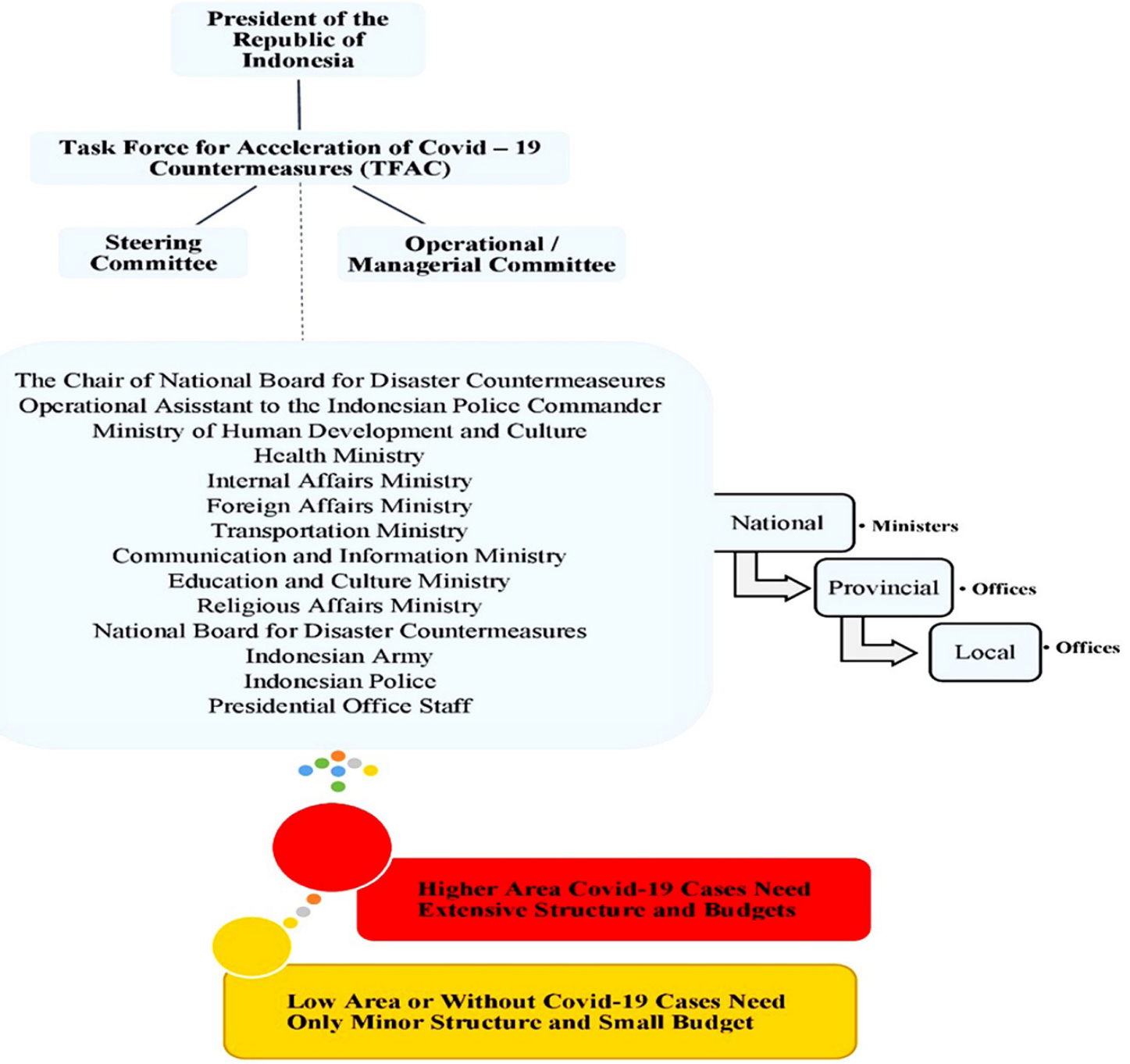

Figure 2. Institutional arrangements for disaster countermeasures in Indonesia (Source: President Decree Number 7/2020) 
With these institutional arrangements, the differences between the rules and structures for the various disasters in Indonesia can be seen. A mass level and long-term disaster such as Covid-19 is managed nationally by a specific task force coordinated by BNPB based on a Presidential Decree, which sets out certain standards pertaining to rules and structures, but also provides room for modifications depending on different situations and conditions (See figure 2). The mega-magnitude 2004 tsunami was also managed nationally by the BNPB, although not all provinces in Indonesia were affected. Some disasters have been managed provincially when they have affected more than one regency/city, such as the tsunami in Palu/Donggala in Central Sulawesi Province in 2018 and the earthquake in Nusa Tenggara Barat, also in 2018. The 2018 South Lampung tsunami was managed by the local South Lampung BPBD, since it only affected that regency (Darmastuti and Rosalia, 2019).

\subsection{Arrangements for the articulation of major risks from disasters}

Based on its legal standing, the BNPB developed the Strategic Plan of 2015-2019. In addition, it also developed the National Plan for Disaster Countermeasures of 2015-2019 (BNPB, 2015b). The differences between the two documents are that the first is focused on strategic issues such as the concept, legal basis and objectives, assessment of challenges, vision and mission statements, objectives, direction, and performance target of the BNPB, while the latter (National Plan for Disaster Countermeasures) is directed towards four national policy directions, namely implementation of: (1) integrated disaster risk reduction; (2) effective emergency management; (3) efficient rehabilitation and reconstruction; and (4) systems and mechanisms of accountability and transparency, as well as good governance of disaster countermeasures at national and local levels.

Based on National Plan 12, major disasters have been identified as posing major risks in most parts of Indonesia. These include earthquakes, tsunami, volcanoes, landslides, flooding, flash-floods, drought, extreme weather, high tides and abrasion, forest and field fires, epidemics, and technological failures. The National Plan also contains assessment of the area distributions of each of the 12 types of disaster all over Indonesia, the potential damage and casualties, and financial losses. Based on this information, the National Plan developed a Disaster Risk Index (Indek Resiko Bencana/IRB) for each province and regency/city in Indonesia. The assessment is comprehensive and informative. However, the data, as the basis of the assessment, does not cover a long period, meaning some areas that are clearly prone to certain types of disaster are not listed as tsunami disaster-prone areas (for instance, Lampung and Banten are not listed as areas prone to tsunami since the eruption of Krakatau Mountain in 1883 is not recorded in more recent data). Articulation of disaster issues is also dependent on the political will of each regime (provincial and regency/local), the commitment of leaders, and the consistency of human resource and financial support.

In general, Indonesia's institutional arrangements for disaster countermeasures are organized using a mix of vertical and horizontal approaches, in which units for the prevention, preparedness, response and recovery of crises and disasters are arranged vertically, but based on the National Strategy of the BNPB as well as Law number 23/2014 juncto Law number 9/2015 regarding Local Government those institutions have to work together horizontally. At the national level, the most important institutions responding to crisis and disaster are the National Search and Rescue Agency, the BNPB and the Indonesian Red Cross. Other responsible institutions include the Ministry of Social Affairs (provision of food and shelter and other immediate survival kits), the Ministry of Health (processing the identification of victims and health service provision); and the police and army (provision of safety and order). A current issue regarding the institutional arrangements for disaster 
countermeasures is the overlapping functions of the National Search and Rescue Agency with those of the BNPB.

Some institutions have functions for prevention and preparedness. These include (1) the Center for Volcanology and Mitigation of Geological Disasters; (2) the Board for Meteorology, Climatology, and Geophysics; and (3) the Board for Research and Application of Technology (in the case of tsunami early warning system development). The functions of prevention and preparedness are also conducted at provincial and local levels, especially through branches of the respective national bodies. However, some cases show that prevention and preparedness are sometimes affected by the inability to apply policies and regulations due to the nature of Indonesian geographical conditions, the lack of human resources, lack of funding, and problems of coordination. Institutions for rehabilitation and reconstruction include the National Land Entitlement Board (for entitlement identity reproduction); the Ministry of Public Work (provision of temporary and permanent housing for victims); and provincial and local government (provision of housing areas). The speed of rehabilitation and reconstruction after disasters in Indonesia is critical due to aspects such as the availability of land and funds, complicated administrative procedures, and the complex social and cultural conditions of the affected communities.

\subsection{Crisis and disaster countermeasures in Indonesia: lesson learned from natural disasters and other crises}

Other than the Covid-19 pandemic, recent disasters in Indonesia gave examples of whether the disaster institutional arrangements are working or not. The earthquake and the following tsunami, together with the liquefaction in Palu and Donggala, Central Sulawesi on 28 September 2018 are an example of complex, difficult situations with critical conditions for countermeasures. Among these were difficulties for rescuing victims due to the occurrence of a very rare disaster, liquefaction, in which a large part of the affected area is submerged and lost below the surface (BBC Indonesia, 2018). Coordination between stakeholders (international, national, provincial and local) was problematic, which led to a delayed response and dissatisfaction both among the organizational stakeholders and the victims of the disaster. This resulted in days of mass lootings and disorder among community members and was largely criticized; only then was order restored and the response able to start to work. The severity of the disaster destroyed almost all the infrastructure, including communication, which made coordination, as well as efforts to combat fake news, difficult. It almost crippled the government. These multiple factors created a poor lesson in natural disaster countermeasures.

The more recent 22 December 2018 tsunami that hit Lampung and Banten Provinces was an example of a quite good disaster management response. Although the tsunami was a new phenomenon (with no recorded history of a huge landslide from the top of the mountainonly island of Krakatau to the bottom of the surrounding sea), the response to the disaster was quick and well managed. Observations on the third day after the tsunami showed almost all the victims had been rescued; the large number of of rescue squads, volunteers, aid workers and donations were well directed, which made emergency aid accessible by the victims. Health services were made available on the second day, together with other supplies for the victims, which prevented a worsening of their conditions. This quite successful disaster management was made possible by several critical aspects: (1) government up to the village level was still functional; (2) destruction to infrastructure, including communication, was minimal, so efficient communication was possible; and (3) the two locations were very close to central government, which allowed aid to reach the area and the victims more quickly.

These two disasters, as well as the Covid-19 pandemic, provide examples of how government institutions, which have the main responsibilities in disaster countermeasures 
and are based on the same regulations (law on the lower level regulations), in reality develop rules and structures which may differ from one other. The Covid-19 pandemic has triggered the establishment of nationwide long-term task forces at national, provincial, and local levels. In some areas, this task force extends to subdistrict and even village and neighborhood levels. Areas with red-zone status (high outbreak risk) have developed much stronger institutions and provided higher budget diversion than yellow (low outbreak risk) and green (no local transmission) status areas. Each level task force may also work together with different disaster stakeholders, who may come from the private sector, nongovernment organizations, community- based organizations, or professional groups. The Presidential, Governor, and Regent/Mayor Decrees have been the main legal basis for regulation and institutional establishment; however, they all provide scope for institutional adaptation to exogenous factors, especially the threat of the Covid-19 pandemic.

Other disasters may need a national task force, but which is only functional in some provinces depending on the potential level of disaster, or the province, or even only local level task force. Most disasters in Indonesia are local in nature, such as flash floods, fires, forest fires, landslides, and drought. Earthquakes may need provincial or national task force when combined with tsunami. This implies that not only will the structures be different, but also the use of budgets, mobilization of manpower, and the use of other resources will vary. The choice of these arrangements is, by and large, unpredictable in nature, as the constructivist institutionalism theory suggest that most of the time institutions are faced with unpredictable exogenous factors. Using other theory to analyze institutional arrangements for disaster countermeasures, especially rational choice, would be difficult and may be unfruitful.

It is important to note that studies related to the current Covid-19 pandemic in other countries show that other countries have also established structural institutions, responses and management for Covid-19 which are different from institutions for other crises and disasters. The studies conducted by Cesarec et al. (2020), Mikac (2020) and Smajić (2020) have revealed that the Republic of Croatia, Republic of Bosnia and Herzegovina and the European Union (EU) have been forced to quickly adjust their institutional structures to respond to the unprecedented threat of the pandemic. These countries and the EU had not fully anticipated the preparedness phase of Covid-19 countermeasures. However, in the response phase of these, all made quick adjustments to policies, structuring and facilitating responses, as well as coordinating with other institutions at national, regional and global levels. However, the question still remains as to whether they will able to cope with the magnitude of the remaining problems (health, economic and social) in the recovery phase.

This response and recovery phase will critically dependent on certain factors, some of which may be external, especially in the current Covid-19 pandemic. First, responses to large-scale disasters are influenced by cooperation and help from the international community. The pandemic definitely shows this need, such as the success of lockdown and containment of people's cross-border movements. Second, the availability of certain critical supplies and medicines is also highly dependent on international cooperation and help. Covid-19 vaccines are a clear example of such a need. Third, the availability of experts can also be dependent on external sources. We have learned that in countering disasters, nations, no matter how advanced they are, still need regional and international help and cooperation. This exogenous factor is similarly critical to the internal preparedness of a nation in constructing institutional arrangements for disaster countermeasures.

\section{Conclusion}

Indonesia has experienced disasters on many scales and magnitudes, from small insignificant ones, up to extremely disastrous ones. Systematic study regarding institutional 
arrangements for disaster countermeasures based on new theoretical perspectives needs to be conducted to enable analysis of phenomena which may contribute new insights. This constructivist perspective study is expected to contribute new insights which supplement the most commonly used theories of rational choice and network new institutionalism.

Although the institutional arrangements for disaster countermeasures in Indonesia are based on the same law, the implementation of institutional structuring as well practices in disaster counter measurements vary greatly. Moreover, it is important to establish taskforces at all levels that are given mandates to establish necessary structures and to divert budgets from regular conventional processes to fast-track more flexible ones.

Other disasters than the current Covid-19 pandemic are mostly managed through smaller institutional arrangements, whether nationally, provincially or locally. National disasters are usually managed directly by $\mathrm{BNPB}$, while those at provincial and local levels are managed by the respective institutions. This implies flexibility in arranging budgets for disaster countermeasures; budget diversion is not easily done, even by government institutions, when implementing disaster countermeasures. Finally, this study demonstrates that the choice of the constructivist theoretical perspective provides richer understanding of how institutions work in countering disasters, by adjusting to exogenous unpredictable factors.

\section{Acknowledgements}

The author would like to thank to some of colleagues at Department of Government Studies, University of Lampung who provided a constructive comment in the early draft of this manuscript.

\section{References}

Amore, A., \& Hall, C.M. (2015). From governance to meta-governance in tourism? Reincorporating politics, interests, and values in the analysis of tourism governance. Tourism Recreation Research, 41(2), 109-122. doi:10.1080/02508281.2016.1151162

BBC Indonesia. (2018). Gempa, tsunami dan likuifasi: Rangkaian bencana di Palu yang perlu Anda ketahui. Available at https://www.bbc.com/indonesia/indonesia-45832237 [Accessed December 5th, 2020]

Beisheim, M., Ellersiek, A., Goltermann, L., \& Kiamba, P. (2017). Meta-governance of partnership for Sustainable Development: Actor's Perspective from Kenya. Public Administration and Development, 38(3), 105-119. doi:10.1002/pad.1810

Bell, S., \& Park, A. (2006). The problematic metagovernance of networks: Water reform in New South Wales. Journal of Public Policy, 26(1), 63-83. doi:10.1017/S0143814X06000432

BNPB. (2015a). Strategic Plan of the Board for Disaster Countermeasures 2015-2019. Badan Nasional Penanggulangan Bencana Indonesia.

BNPB. (2015b). National Plan for Disaster Countermeasures. Badan Nasional Penanggulangan Bencana Indonesia.

BNPB. (2020). Bencana Indonesia 2020. Badan Nasional Penanggulangan Bencana Indonesia.

Boin, A, Ekengren, M., \& Rhinard, M. (2006). Functional Security and Crisis Management Capacity in the European Union, Forum for Security Studies (EUROSEC) at the Swedish National Defence College (SNDC) and the Leiden University Crisis Research Center (CRC) [Online]. Available at http://citeseerx.ist.psu.edu/viewdoc/ download?doi=10.1.1.138.2159\&rep=rep1\&type=pdf [Accessed January 28th, 2017]

Cesarec, I., Mikac, R. \& Spevec, D. (2020). The Concept of Human Security as a Basis for the 
Application of Big Data Concept in Establishment of Early Warning System for Crisis Management in the Republic of Croatia. Croatian International Relations Review, 26, 72-95.

Darmastuti, A., \& Rosalia, F. (2019). Metagovernance on Disaster: Learning from Lampung Tsunami in Indonesia. Proceedings of the 2nd International Conference of Science Education in Industrial Revolution 4.0 (ICONCEIR), December 17th, Medan, North Sumatra, Indonesia.

Goyal, N. (2019). Disaster Governance and Community Resilience: the Law and Role of SDMAs. International Journal of Disaster Risk Management, 1(2), 61-75. doi:10.18485/ijdrm.2019.1.2.5

Jackson, R. L., Drummond, D. K., \& Camara, S. (2007). What is qualitative research?. Qualitative research reports in communication, 8 (1), 21-28. doi:10.1080/17459430701617879

Jones, S., Oven, K.J., Manyena, B., \& Aryal, K. (2014). Governance struggles and policy processes in disaster risk reduction: A case study from Nepal. Geoforum, 57, 78-90 doi.org/10.1016/j.geoforum.2014.07.011

Kompas. (2019). Data Bencana BNPB pada 2019, 1538 Kejadian dan 325 Korban Meninggal. Available at https://nasional.kompas.com/read/2019/04/30/19322341/data-bencanabnpb-pada-2019-1538-kejadian-dan-325-korban-meninggal [Accessed December 5th, 2020]

Malalgoda, C., Amaratunga, D., \& Pathirage, C. (2010). Role of local governments on disaster risk reduction. Paper presented at COBRA 2010 - Construction, Building, Real Estate Research Conference of the Royal Institution of Chartered Surveyors, Al Dauphine Universite, Paris, France.

March, J. G. \& Olsen, J. P. (2006). Elaborating the "new institutionalism". The Oxford handbook of political institutions, 5, 3-20.

Mikac, R. (2020). COVID-19 Pandemic and Crisis Management in the Republic of Croatia. Anali Hrvatskog politološkog društva: časopis za politologiju, 17, 31-55.

Persson, T.A., \& Povitkina M. (2017). 'Gimme Shelter'; The Role of Democracy and Institutional Quality in Disaster Preparedness. Political Research Quarterly, 70(4), 833-847. doi: $10.1177 / 1065912917716335$

President of the Republic of Indonesia Decree number 7/2020 on the establishment of TFAC at the national level.

Rhodes, R. A., Binder, S. A. \& Rockman, B. A. (2006). The Oxford handbook of political institutions, Oxford University Press.

Smajić, M. (2020). Covid-19 Crisis Management: Case Study of Bosnia and Herzegovina. RACVIAC Newsletter Special edition.

Stark, A. (2014). More micro than meta? Competing concepts of metagovernance in the European Union. Public Policy and Administration, 30(1), 73-91. doi:10.1177/0952076714543862

Voice of Indonesia. (2019). BNPB: Ada 3.768 Bencana Terjadi di Tahun 2019. Available at: https:/ / voi.id/berita/1263/bnpb-ada-3-768-bencana-terjadi-di-tahun-2019 [Accessed December 2nd, 2020]

Walch, C. (2017). Adaptive governance in the developing world: disaster risk reduction in the State of Odisha, India. Climate and Development, 11(3), 238-252. doi:10.1080/17565529.2018. 1442794 